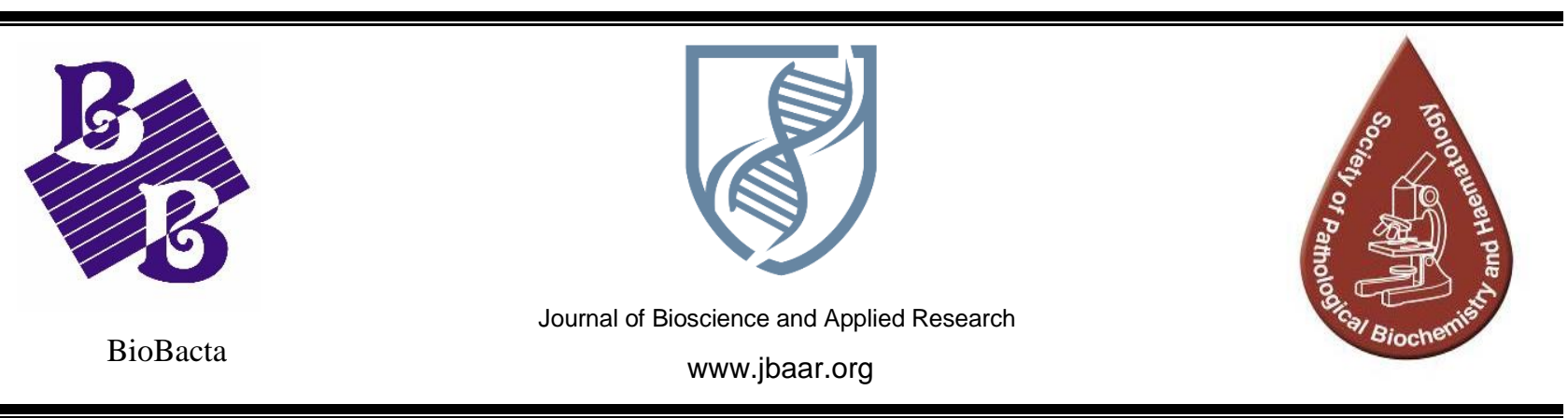

\title{
Gonad variation and development of freshwater mussel Chambardia rubens Lamarck, 1819 (Bivalvia: Mutelidae) from the River Nile in Egypt
}

\section{Mostafa Morad $^{1 *}$, Mona Fathi Fol ${ }^{2}$, Irene Sameh Gamil ${ }^{1,}$ and Reda Mohammad Mansour ${ }^{1}$}

1- Zoology and Entomology Department, Faculty of Science, Helwan University, Egypt.

2- Zoology Department, Faculty of Science, Cairo University, Egypt.

*Corresponding author, E-mail: myame_mostafa@yahoo.com

\section{DOI: 10.21608/jbaar.2018.154710}

Abstract: The gametogenesis, reproductive cycle, and larval morphology of Chambardia rubens (Bivalvia: Mutelidae) are studied for the first time in Egypt. A total of 46 mussels were collected seasonally from winter to autumn 2017 from Benha (Qaluobiya Governorate) along the River Nile in Egypt. Histological examinations demonstrate that $C$. rubens is a dioecious species and 22 were females with a prevalence rate of $47.8 \%$ and 24 were males with a prevalence rate of $52.2 \%$. The gonads of both male and female specimens were found to be paired and symmetrical organs, situated between the digestive gland and intestine. Oogenesis was divided into four stages; oogonia, previtellogenic oocytes, vitellogenic oocytes, and postvitellogenic oocytes while spermatogenesis passed through spermatogonia, spermatocytes, spermatids, and spermatozoa. Sperm morulae were also detected. The reproductive cycle was intense in winter including the four developmental stages of gonads; developing, ripe (mature), spawning, and spent stages, respectively. The eggs and larval stages (lasidia) were incubated for a short period within the inner demibranchs so C. rubens can be considered as endobranchous and tachytictic brooders. Light microscopy revealed that the eggs with vitelline membrane and the larvae contain internal threads with an anterior outgrowth. Scanning electron microscopy examinations revealed that the eggs are with smooth membrane without any folds with the presence of anterior outgrowth in the larvae.

Keywords, Bivalvia, Mutelidae, Chambardia rubens, gametogenesis, reproductive cycle, larval morphology.

\section{Introduction}

Knowledge of the various Egyptian freshwater molluscs and their reproductive biology is rather insufficient and most studies paid attention mainly to species that play an important role in transmitting diseases to man and animals (Fol, 2008).

Reproduction is known to be the most important factor influencing the abundance and distribution of a given molluscan species in any habitat. Moreover, it plays a major role in the taxonomical discrimination of different species, especially in bivalve species that possess various overlapping morphological features (El-Assal et al., 2010). The reproductive characteristics and processes found in the unionoidea are diverse, complex and exhibit extraordinary variations in fecundity, brooding tendencies, and host specificity (Haag and Staton, 2003)

There are different ways for assessing gamete development in bivalves, most of which are occurred by visual observation of the relative size, shape, and color of the gonads or investigating developmental stages, based on histological characterization (Asma et al., 2014). Moreover, the 
use of indices such as gonad development index for individuals, mean gonad index for populations has been used in many studies to determine gonad status (Moullac et al., 2009). Since histological techniques provide extensive information about gonad development, these are widely used to investigate reproductive events (Lango- Reynosoa et al., 2000). However, almost nothing is known about the basic biology and reproduction of any of the unionidean species found in Egypt beyond the information provided on the anatomy of one species by Soliman (2001) and a description of the early developmental stage of C. aegyptiaca by Varjabedian (2006). The present study aims to examine the gametogenesis and the reproductive cycle of $C$. rubens for the first time in Egypt as well as its developmental stages and lasidial development in the marsupium during the brooding period.

\section{Materials and Methods}

Collection of samples: A total of 46 specimens of C. rubens was collected seasonally from winter to autumn 2017 from Benha (Qaluobiya Governorate) along River Nile in Egypt using a special net made of the hard metallic frame, provided with wire and divided into squares of about $0.2 \mathrm{~mm}$ in diameter like a mesh. Collected mussels were transferred to the laboratory of Invertebrates \& Parasitology, Faculty of Science, Cairo University then sorted and maintained under the same conditions of food and temperature.

Identification of mussels took place according to Ibrahim et al., (1999) and Graf and Cummings, (2007) then sorted in 7\% formalin solution. After removing the marsupia (swollen ctenidia), eggs and late larval stages (lasidia) were examined under a stereomicroscope and photographed using a micrometer-calibrated Leica research photomicroscope.

Histological examination: Gonads were removed and processed according to Carleton et al. (1967), fixed in $10 \%$ formalin for 12 hrs., dehydrated in ascending series of ethanol concentration $(80 \%$, $90 \%, 100 \%, 3 \mathrm{hrs}$. for each), cleared in 2 changes of xylene (30 min. for each) and embedded in paraffin. Sections were cut by a microtome in $5 \mu \mathrm{m}$ thickness, mounted on slides, dewaxified in xyline, stained with Haemtoxylin and Eosin then covered by glass slips using Canada balsam.

Scanning electron microscope study: Eggs and larval stages were washed in $0.7 \%$ saline, fixed in $2.5 \%$ gluteraldehyde $(\mathrm{pH} 7.4)$ at $4{ }^{\circ} \mathrm{C}$, washed 3 times in phosphate buffer, postfixed in $1 \%$ osmium tetraoxide in $0.1 \mathrm{M}$ phosphate buffer, and dehydrated through graded series of ethanol (70\%, $80 \%, 90 \%, 95 \%$ and 2 changes of absolute ethanol). Larvae were then mounted on stubs with doubleadhesive tapes, coated with gold using spinoculevac/ sputter coater. Samples were examined and photographed using a scanning electron microscope (SEM) (JOEL 1200 EX II) at the central laboratory in the Faculty of Science, Ain Shams University, Egypt.

\section{Results}

\section{A- Sex ratio (prevalence):}

Histological examination of the gonads revealed that the species under investigation are gonochoric. Out of 46 specimens examined, 22 were found to be females and 24 were found to be males with prevalence rate of $47.8 \%$ and $52.2 \%$, respectively.

After removal of the shell, the bilobed mantle was exposed and enclosed the soft parts (visceral mass, labial palps, foot, and demibranchs) as a typical bivalve mollusc (Fig. 1). In the present investigation, the histological observations revealed that the gonads surrounded the digestive gland and intestine. They were diffused organs, consisting of highly branched follicles "acini" surrounded by connective and muscular tissues, which may vary in density according to the gamete developmental stages (Fig. 2).

\section{B- Gametogenesis:}

\section{I- Oogenesis (Figs. 3-6):}

The oogenesis developed in the oogenic follicles is divided into the following four stages:

\section{Oogonia $(\mathrm{Og})$ :}

The majority of the ovarian follicles exhibited developing oogonia attached to the inner acinar walls. Oogonia were found to be round or spherical (Fig. 3).

\section{Previtellogenic oocytes (PVO):}


Oogonia grow and developed into previtellogenic oocytes characterized by irregular edges with a diameter larger than that of oogonia and were generally located at the periphery of the germinal vesicle (Fig. 4).

\section{Vitellogenic (mature) oocyte (Vo):}

Oocytes entering the vitellogenesis stage had continued in growing while they were migrating into the acinar lumen by accumulating yolk granules in the cytoplasm. Oocytes are connected through a junction with the acinar wall known as the egg stem or stalk. Common structures in vitellogenic oocytes were vitelline bodies which developed significantly as vitellogenesis progresses. The nucleus of vitellogenic oocytes was round (Fig. 5).

\section{Postvitellogenic oocytes (Pv):}

Postvitellogenic oocytes had a polyhedral appearance at the acinar lumen and were deformed by compression in the mature gonad with a larger diameter (twice that of vitellogenic oocytes). No joints between oocytes and follicular walls were observed at this stage. The nucleus showed a significant number of projections into the cytoplasm (ooplasm) (Fig. 6).

\section{II- Spermatogenesis (Fig. 7):}

The spermatogenesis had followed a similar continuous pattern as seen in females occurring all the year although it was more evident during winter and spring. Four main stages of development were recorded as follows:

\section{Spermatogonia:}

They were oval growing out of the acini wall with relatively little cytoplasm and located at the acinus periphery. These cells were divided and formed the spermatocytes.

\section{Spermatocytes:}

They were spherical cells with a large homogeneous nucleus without visible nuclear membrane and their nucleolus was not detected. Spermatocytes were smaller than the spermatogonia and developed into spermatids.

\section{Spermatids:}

They were polyhedral in shape with a completely homogeneous nucleus and darkly stained, distributed in the middle of the lumen of the acini. The spermatids developed into spermatozoa.

\section{Spermatozoa:}

Spermatozoa were often found in groups close to the acinus lumen, smaller than the spermatids with bullet-shaped structures. The male follicles of species under investigation showed the presence of early spermatids clusters called sperm morulae during the winter season (Fig. 7 inset).

\section{C- Reproductive cycle (Figs. 8-15):}

The reproductive cycle has consisted of the following four stages:

\section{1- Developing Stage:}

The gonadal follicles were few and their sizes started to increase. Spermatogonia and spermatocytes started to grow in male follicles (Fig. 8) while in female follicles, oogonia and previtellogenic oocytes were found (Fig. 12). Moreover, connective tissues started to decrease in size.

\section{2- Ripe (mature) stage:}

The follicles were polygonal in shape, increased in size, and occupied the entire tissue. In the lumen of female follicles, free ripe oocytes almost occupied the center (Fig. 13) while spermatozoa occupied most of the male follicles (Fig. 9). Connective tissues decreased greatly in size in both male and female follicles.

\section{3- Spawning Stage:}

The follicles started to decrease in size. There were many empty spaces between and within the follicles. In females, free ripe rounded oocytes in the lumen and empty spaces were observed (Fig. 14) while in males, many spermatozoa were found in gonoducts and interfollicular space (Fig. 10). Connective tissues started to increase in size.

\section{4- Spent (cytolyzed) Stage:}

The gonadal follicles in both males and females were empty, except for residual gametes. Follicles collapsed with large empty spaces in the follicular lumen. Connective tissues started to fill the gonad (Figs. 11, 15).

\section{D- Fertilization:}

The gametogenesis was synchronous where the oogenesis and spermatogenesis were intense during the late winter season. The developing stage started in late winter where the oogonia and previtellogenic 
cells have been noticed in female follicles (Figs. 3, 4) while the spermatogonia, spermatocytes, and little few spermatozoa were shown in the male follicles (Fig. 7) in addition to the appearance of sperm morulae (Fig.7 inset). The ripe stages started to appear in early spring (Figs. 9, 13). The mature oocytes emerged from the ovarian follicles to the suprabranchial cavity where the fertilization process had been occurred by the discharged sperms during early spring. The female follicles showed a spawning period after the fertilized oocytes started to migrate to the inner demibranch during the late spring season (Fig.14). Different lasidial stages were also noticed during the late spring season. The spent period lasted from summer until winter seasons where the male and female gonads were ready for a new breeding cycle (Figs. 11, 15).

\section{E- Brooding and developmental larval stages} (Figs. 16-21):

The examination of brooded specimens showed that several hundreds of fertilized eggs and larvae could be detected between the gill lamellae of the inner demibranchs only at certain times during different seasons. Marsupial gills were noticed during the spring season only (Figs. 16, 17).

Light microscopy examination of the marsupial gills revealed that the eggs had a brown color, spherical shape with a thin vitelline membrane, and no prominent jelly coat (Fig. 18), while SEM observations showed a distinctive feature for eggs where they were smooth without any folds (Fig. 19). The larvae contained an anterior outgrowth with threads inside the transparent membrane (Fig. 20). Besides, SEM studies showed that the larva was elongated with an outgrowth anteriorly (Fig. 21).

\section{Discussion}

Studies on gametogenesis in bivalves have primarily paid attention to economically important species (Ituarte, 2009) and little is known on the gametogenesis in unionid mussels. Gametogenesis has been histologically determined using various methods to find out the timing of reproductive cycles and provide evidence for gamete production and development within acini. Until recently, the gametogenetic cycle for many unionids in Egypt was unknown and there was no information available on the reproductive biology and gonad development of this species (Fol, 2012).

Concerning reports dealing with African iridinids, Heard and Dougherty (1980) refer to Aspatharia (Spathopsis) (Chambardia) and Mutela spp. as containing hermaphroditic individuals, without any documentation or qualification. In the present study, the freshwater mussel Chambardia rubens was confirmed to be a diocioeus species with a 0.91:1 male to female sex ratio, respectively. These findings agreed with Çek and Şereflişan (2006) and Şereflişan et al. (2009) who stated that unionoid sexes are generally separate but functional hermaphroditism occurs when population density is low. Sex ratios in bivalve populations are usually close to $1: 1$, however, examples of sex ratios biased toward either females or males have been reported. Generally, there seems to be a correlation between sex ratio and habitat. For some freshwater and brackish water species, the sex ratio varies with age, with the direction of the juvenile sex bias being species-specific (Morton, 1985).

Oogenesis is a continuous process, three phases of oogenesis are generally distinguished: previtellogenesis, vitellogenesis, and postvitellogenesis oocytes. In general, the three phases can be classified by the level of uptake of vitellogenin or yolk protein via microvilli (Camacho-Mondragón et al., 2015). On the other hand, spermatogenesis is generally distinguished by four different stages, spermatogonia, spermatocytes, spermatids, and sperms (Çek and Şereflişan, 2011). Oogenesis in bivalves has been classified into solitary or follicular types. In solitary oogenesis, the developing oocyte is not surrounded by follicle cells (Ituarte, 2009) while surrounded by follicle cells in follicular type from the acinus to a variable degree (Ituarte, 2009). Also, follicle cells surround oocytes when they are free in the acinus lumen in Patinopectin yessoensis and Crenomytilus grayana (Eckelbarger and Davis, 1996). The present study revealed that species under investigation displayed the solitary type oogenesis that started with oogonia followed by previtellogenic, vitellogenic, and finally, postvitellogenic oocytes. Also, the spermatogenesis showed the four stages; spermatogonia followed by spermatocytes, spermatid, and finally, spermatozoa. Similar results 
were obtained by Camacho-Mondragon et al. (2015) in their studies on the pen shell Atrina maura.

In contrast, Hinzmann et al. (2013) have divided oogenesis mainly into five continuous stages that occur consecutively in their work on the gametogenesis of Anodonta anatine; (i) oogonia; (ii) previtellogenic oocytes; (iii) early oocytes; (iv) oocytes; and (v) mature oocytes, while the spermatogenesis was divided into four stages similar to the present observations. Wu et al. (2017) also found that the oogenesis of Hyriopisis schlegelii had four stages including oogonia, primary oocytes, secondary oocytes, and mature oocytes. Spermatogenesis was developed during five stages including spermatogonium, primary spermatocyte, secondary spermatocyte, sperm cells, and sperm.

In the present study, $C$. rubens revealed clusters of early spermatids in the male follicles called sperm morulae during the winter season. This observation agreed with Shepardson et al. (2012) who stated that cellular clusters termed as sperm morulae were previously reported to occur in several bivalve species. Moreover, their origin and function have been attributed to atypical spermatogenesis.

In contrast, somatic host cells containing several spermatids organized under morula-like structures in Prisodon alatus, resembling the morula stages of ontogenetic development, were detected in the study of Matos et al. (1998) who considered that the development of numerous clusters of spermatids forming morulae is a result of a natural spermiogenesis in which the spermatids metamorphose into mature spermatozoa. Eckelbarger et al. (1990) suggested that somatic host cells seem to play some role in spermatic cell maintenance and nutrition. However, in other species, the morulae were described as grouped spermatozoa (Buckland-Nicks and Chia, 1986).

In most freshwater and marine bivalves, the reproductive cycle is divided into 3-7 stages such as resting, developing, maturation (ripe), spawning, and spent (Ilano et al., 2007; Labecka and Domagala, 2016). In the present investigation, it was found that the reproductive cycle is composed of four periods; developing, ripe, spawning, and spent stages. The resting stage was not noticed during this study. The gametogenesis was synchronous between male and female species and intense during the spring season. Besides, the spawning season occurred synchronously between sexes and relatively soon after gamete production and lasted from late spring until early summer.

The present study agreed with CamachoMondragon et al. (2012) who found that the resting phase wasn't observed in their study. They referred to the lack of a reproductively inactive period (resting phase) in this population as a response to local environmental conditions, particularly food availability (Baqueiro and Aldana, 2000; VillalejoFuerte et al., 2018). Moreover, the reproductive cycle of suspension feeders is not only influenced by physical parameters such as surface temperature, increase or decrease in water levels, but also by changes in phytoplankton biomass and species compositions (Herrmann et al., 2009).

Bivalves have been also classified according to two spawning patterns into tachitictic, with short and limited reproductive periods, and braditictic, with extended periods of reproductive activity (Fretter, 1984). The present study indicated that $C$. rubens had short spawning periods that lasted from spring till early summer in contrary to those of other mussel species (Garner et al., 1999; Çek and Şereflişan, 2006). Therefore, this species might be classified as tachitictic brooder species.

Unionaceans, in which brooding occurs in all four demibranchs (tetragenous), is considered to be a primitive type. Hoeh et al. (1996 and 2001) considered that the African Coelatura was the most primitive unionid as it was tetragenous. Moreover, Ituarte (2009) reported that fertilized eggs and embryos were attached to the inter-filamental junctions of ascending and descending branchial filaments of both the inner and the outer demibranchs. Evolutionary modifications to the primitive brooding plan involved the acquisition of marsupia restricted to the inner (endobranchy) or outer (ectobranchy) demibranchs only or to distinctive positions within the demibranchs (Jupiter and Byrne, 1997).

The present study showed that the interlamellar spaces of the inner demibranchs only were populated with fertilized eggs and different lasidial stages, so $C$. rubens is considered an endobranchous species. Similarly, the bivalves of the family Mycetopodidae incubated their eggs in internal demibranchs, in a so-called marsupium (SilvaSouza et al., 2011). Moreover, In Hyridella depressa 
(Bivalvia: Hyriidae), the marsupia were restricted to the mid-portion of the inner demibranchs and the interlamellar septa are distinctly thickened (Jupiter and Byrne, 1997)

On the contrary, Tankersley and Dimock, (1991) stated that both outer demibranchs of Anodonta cataracta served entirely as a pair of marsupial chambers and undergo pronounced morphological and architectural changes to accommodate nearly a million developing larvae. Also, Labecka and Domagala, (2016) found that Sinanodonta woodiana (Bivalvia: Unionoidea) brood eggs and developing glochidia within swollen outer demibranchs only .

There had been various speculations on the adaptive advantages of brooding; include protection from unfavorable, environmental conditions and predators (Andrade- Villagrán et al., 2016). Also, it might facilitate the transfer of maternal nutrients to the developing larvae. This adaptation was considered to be important concerning the low ion concentrations characteristic of freshwaters (Tankersley and Dimock, 1991).

Many studies indicated that larval stages and their various morphological and behavioral types have important characters in the freshwater mussel systematic for over many years (Pfeiffer and Graf, 2012). All attention has been paid to the glochidia of Unionidae, whereas the early developmental stages of haustoria (lasidia) in mutelid species from the River Nile in Egypt were still in need of further elucidation (Varjabedian, 2006). Although, the larval types and early postlarval biology in Uniondae have been given a detailed description by Wächtler et al. (2001) and they reported full notifications about the glochidium, only very little attention has been recorded concerning the early developmental stages of haustoria or lasidia of the Mutelidae. Rand and Wiles (1982) and Waller et al. (1988) used SEM to show that these techniques were successful in identifying the larval stages of different species.

In the present study, eggs and larval stages appeared simultaneously within the inner demibranchs in the spring months of the studied year and juvenile stages were released at the lasidia stage. Light microscopy examination showed that the eggs of $C$. rubens obtained from the marsupial gills are spherical and surrounded by a thin vitelline membrane. On the other hand, it appeared smooth under SEM. The larvae showed anterior outgrowth with light and SEM microscopes.

The use of shell morphometrics such as length, height, and thickness has proved useful in identifying larvae (Gribben and Hay, 2003). In the present study, the mean diameter of the egg of the studied species ranged between 37.4 to $60.5 \mu \mathrm{m}$, while the larval lengths measured ranged from 82.5 to $110 \mu \mathrm{m}$. On contrary, Jupiter and Byrne (1997) found that the larvae with a mean length of $243 \mu \mathrm{m}$. Moreover, Fryer (1961) found that the mature larva of Mutela bourguignati was longer than the species under investigation and measured $200 \mu \mathrm{m}$. Also, the mature larva of $M$. rostrata measured $200 \mu \mathrm{m}$ in the study of Varjabedian (2006).

\section{Conclusion:}

The present study is the first to describe the reproductive biology of the freshwater mussel, Chambardia rubens in Egypt. However, additional research is still needed to improve the knowledge of reproductive biology, seasonal gonadal changes, and a spawning regime of the freshwater bivalves in Egypt, especially concerning the release and collection of their youngs. This is essential for developing management strategies for threatened species, for example, protecting spawning stock and determining the timing of larval settlement.

\section{Acknowledgments:}

The authors are thankful to the Faculty of Science, Helwan University, Cairo, Egypt, for providing all the facilities used to complete this work.

\section{References:}

Andrade-Villagrán, P. V.; Chaparro, O. R.; Pardo, L. M.; Paredes-Molina, F. J. and Thompson, R. J. (2016): Embryo brooding and its effect on feeding in the bivalve Gaimardia bahamondei Osorio \& Arnaud, 1984. Helgoland Marine Research, 70(1): 70-74.

Asma, M. K.; Saber, K.; Hossein, R. and Zohreh, H. Z. (2014): Seasonal histological comparison of gonad and gametogenesis in female pearl oyster (Pinctada radiata) of the Persian Gulf. Journal of the Persian Gulf, 5(15): 17-24.

Baqueiro, C. E. and Aldana, D. A. (2000): A review of reproductive patterns of bivalve mollusks from Mexico. Bulletin of Marine Science, 66(1): 13-27.

Buckland-Nicks, J. and Chia, F. S. (1986): Fine structure of sertoli cells in three marine snails with a 
discussion on the functional morphology of sertoli cells in general. Cell Tissue Research, 245: 305-313. Camacho-Mondragón, M. A.; ArellanoMartínez, M. and Ceballos-Vázquez, B. P. (2012): Particular features of gonadal maturation and size at first maturity in Atrina maura (Bivalvia: Pinnidae). Scientia Marina, 76(3): 539-548.

Camacho-Mondragón, M. A.; Ceballos-Vázquez, B. P.; Uría-Galicia, E.; López-Villegas, E. O.; Pipe, R. and Arellano-Martínez, M. (2015): Ultrastructural and histological study of oogenesis and oocyte degeneration in the penshell Atrina maura (Bivalvia: Pinnidae). Malacologia, 59(1): 112.

Carleton, M.; Drury, R. A. B.; Willington, E. A., and Cammeron, R. (1967): Carleton's histological technique (Drury and Wallington ed.). Oxford University press.

Çek, Ş. and Şereflişan, H. (2006): Certain reproductive characteristics of the freshwater mussel Unio terminalis delicates (Lea, 1863) in Gölbaşi Lake, Turkey. Aquaculture Research, 37(13): 1305-1315.

Çek, Ş. and Şereflişan, H. (2011): The gametogenic cycle of Leguminaia whaetleyi (Lea, 1862) in the lake Gölbaşi, Turkey (Bivalvia: Unionidae). Journal of Experimental Zoology, 1(315A): 30-40.

Eckelbarger, K. J. and Davis, C. V. (1996): Ultrastructure of gonad and gametogenesis in the eastern oyster, Crassostrea virginica. I. Ovary and oogenesis. Marine Biology, 127(1): 79-87.

Eckelbarger, K. J.; Bieler, R. and Mikkelsen, P. M. (1990): Ultrastructure of sperm development and mature sperm morphology in three species of commensal bivalves (Mollusca: Galeommatoidea). Journal of Morphology, 205(1): 63-75.

El-Assal, F. M.; Varjabedian, K. G.; Tawfik, A. R., and Fol, M. F. (2010): Reproduction and genetic variation in two Corbicula species (Bivalvia: Veneroida) from the River Nile in Egypt. Journal of the Pennsylvania Academy of Science, 84(1): 31-37.

Fol, M. F. (2008): Taxonomical studies on River Nile bivalves Corbicula fluminae (Muller, 1774) and Corbicula fluminalis (Muller, 1774) from Egypt. M.Sc. Thesis, Cairo University.

Fol, M. F. (2012): Taxonomical and biological studies on Coelatura species (Bivalvia: Unionidae) from the River Nile in Egypt. Ph.D. Thesis, Cairo University.

Fretter, V. (1984): Prosobranchs. In: the Mollusca reproduction (Tompa, Verdonk and den Biggelaar eds.). Orlando, Florida, Academic Press. Pp. 1-45.

Fryer, G. (1961): The developmental history of Mutela bourguignati (Ancey) Bourguignat
(Mollusca: Bivalvia). Philosophical Transactions of the Royal Society, 244(B): 259-298.

Garner, J. T.; Haggerty, T. M., and Modlin, R. F. (1999): Reproductive cycle of Quadrula metanevra (Bivalvia: Unionidae) in the Pickwick Dam Tailwater of the Tennessee River. The American Midland Naturlist, 141(2): 277-283.

Graf, D. L., and Cummings, K. S. (2007): Preliminary review of the freshwater mussels (Mollusca: Bivalvia: Unionoida) of northern Africa, with an emphasis on the Nile. Journal of the Egyptian German Society of Zoology, 53(D): 89118.

Gribben, P. E., and Hay, B. E. (2003): Larval development of the New Zealand geoduck Panopea zelandica (Bivalvia: Hiatellidae). New Zealand Journal of Marine and Freshwater Research, 37(2): 231-239.

Haag, W. R., and Staton, J. L. (2003): Variation in fecundity and other reproductive traits in freshwater mussels. Freshwater Biology, 48(12): 2118-2130.

Heard, W. H. and Dougherty, B. J. (1980): An anatomical redescription of Pleiodon (Cameronia) spekii (Pelecypoda: Mutelidae: Pleiodoninae). Malacological Review, 13: 45-53.

Herrmann, M.; Alfaya, J. E. F.; Lepore, M. L.; Penchaszadeh, P. E. and Laudien, J. (2009): Reproductive cycle and gonad development of the Northern Argentinean Mesodesma mactroides (Bivalvia: Mesodesmatidae). Helgoland Marine Research, 63: 207-218.

Hinzmann, M.; Lopes-Lima, M.; Teixeira, A.; Varandas, S.; Sousa, R.; Lopes, A.; Froufe, E. and Machado, J. (2013): Reproductive cycle and strategy of Anodonta anatina (L., 1758): Notes on hermaphroditism. Journal of Experimental Zoology, 319(7): 378-390.

Hoeh, W. R.; Bogan, A. E., and Heard, W. H. (2001): A phylogenetic perspective on the evolution of morphological and reproductive characteristics in the Unionoida. In: Ecology and evolutionary biology of the freshwater mussels, Unionoida (Bauer \& Wächtler, eds.). Ecological Studies, Springer-Verlag, Berlin, 145. Pp. 257-280

Hoeh, W. R.; Stewart, D. T.; Sutherland, B. W., and Zouros, E. (1996): Multiple origins of genderassociated mitochondria DNA lineages in bivalves (Mollusca: Bivalvia). Evolution, 50: 2276-2286.

Ibrahim, A. M.; Bishai, H. M. and Khalil, M. T. (1999): Freshwater molluscs of Egypt. Egyptian Environmental Affairs Agency, National Biodiversity Unit (10).

Ilano, A.; Sotto, F. and Juario, J. (2007): Sexual maturity and reproductive cycle of Paphia textilis 
(Gmelin, 1971) (Bivalvia:Veneroidea) of Sillon waters, Bantayan

Island, Cebu, Philippines. Journal of Aquatic Science, 4: 89-103.

Ituarte, C. (2009): Unusual modes of oogenesis and brooding in bivalves: the case of Gaimardia trapesina (Mollusca: Gaimardiidae). Invertebrate Biology, 128(3): 243-251.

Jupiter, S. D., and Byrne, M. (1997): Light and scanning electron microscopy of the embryos and glochidia larvae of the Australian freshwater bivalve Hyridella depressa (Hyriidae). Invertebrate Reproduction \& Development, 32(2): 177-186.

Labecka, A. M. and Domagala, J. (2016): Continuous reproduction of Sinanodonta woodiana (Lea, 1824) females: an invasive mussel species in a female-biased population. Hydrobiologia, 810(1): 57-76.

Lango-Reynosoa, F.; Chavez-Villalbaa, J.; Cochard, J. and Le Pennec, M. (2000): Oocyte size, a means to evaluate the gametogenic development of the Pacific oyster, Crassostrea gigas (Thunberg). Aquaculture, 190(1-2): 183-199.

Matos, E; Corral, L. and Azevedo, C. (1998): Fine structure of spermiogenesis with special reference to the spermatid morulae of the freshwater mussel Prisodon alatus (Bivalvia, Unionoidea). Journal of Morphology, 238: 63-70.

Morton, B. (1985): The reproductive strategy of the mangrove bivalve Polymesoda (Geloina) erosa (Bivalvia: Corbiculoidea) in Hong Kong. Malacological Review, 18: 83-89.

Moullac, G.; Hui, B.; Vonau, V.; Levy, P. and Cochard, J. (2009): Effect of food conditioning on gonadic activity in the oyster Pinctada margaritifera. $11^{\text {th }}$ Pacific Science Inter-Congress, Tahiti, French Polynesia.

Pfeiffer, J. M., and Graf, D. L. (2012): Evolution of asymmetrical glochidia in the Unionidae (Mollusca: Bivalvia). Annual meeting of the American Society, Cherry Hill, New Jersy.

Rand, T. G., and Wiles, M. (1982): Species differentiation of the glochidia of Anodonta cataracta (Say, 1817) and Anodonta implicata (Say, 1829) (Mollusca: Unionidae) by scanning electron microscopy. Canadian Journal of Zoology, 60(7): 1722-1727.

Şereflişan, H.; Çek, Ş., and Şereflişan, M. (2009): Histological studies on gametogenesis, hermaphroditism and the gametogenetic cycle of
Anodonta gabillotia pseudodopsis (Locard, 1883) in the Lake Gölbaşı, Turkey (Bivalvia: Unionidae). Journal of Shellfish Research, 28(2): 337-344.

Shepardson, S. P.; Heard, W. H.; Breton, S. and Hoeh, W. R. (2012): light and transmission electron microscopy of two spermatogenic pathways and unimorphic spermatozoa in Venus taconcha ellipsiformis (Conrad, 1836) (Bivalvia: Unionoida). Malacologia, 55(2): 263-284.

Silva-Souza, A. T.; Guardia-Felipi, P. and Arrebola, N. R. (2011): Embryonic development of Anodontites trapesialis (Lamarck, 1819) (Bivalvia: Mycetopodidae). Brazilian Journal of Biololgy, 71(1): 139-144.

Soliman, G. N. (2001): Invertebrate zoology, the mideastern invertebrate fauna. Part II: the Coelomates. The palm press, Cairo, Egypt. Pp. 520. Tankersley, R. A., and Dimock, R. V. (1991): Quantitative analysis of the structure and function of the marsupial gills of the freshwater mussel Anodonta cataracta. Biological Bulletin, 182(1): 145-154.

Varjabedian, K. G. (2006): The early development of two unionid bivalves from the River Nile, Egypt. Journal of the Egyptian German Society of Zoology, 50(D): 139-152.

Villalejo-Fuerte, M.; Camacho-Mondragón, M. A.; Ceballos-Vázquez, B. P.; López-Villegas, E. O.; Uría-Galicia, E. and Arellano-Martínez, M. (2018): Ultrastructure of sperm development and mature sperm morphology in Spondylus calcifer and $S$. princeps (Bivalvia: Spondylidae). Malacologia, 62(1): 1-10.

Wächtler, K.; Mansur, M. C. D. and Richter, T. (2001): Larval types and early postlarval biology in naiads (Unionoida). In: Ecology and Evolution of the Freshwater Mussels Unionoida (Bauer and Wachtler eds.). Springer-Verlag press. Pp. 93-125. Waller, D. L.; Holland-bartels, L. W. and Mitchell, L.G. (1988): Morphology of glochidia of Lampsilis higginsi (Bivalvia: Unionidae) compared with three related species. American Malacological Bulletin, 6: 39-43.

Wu, D.; Shi, J.; Peng, K.; Sheng, J.; Wang, J.; Wang, B. and Hong, Y. (2017): Structural characteristics of gonadal development and hermaphroditic phenomenon in freshwater pearl mussel, Sinohyriopisis schlegelii (Hyriopisis schlegelii). Tissue Cell, 49(3): 440-446. 

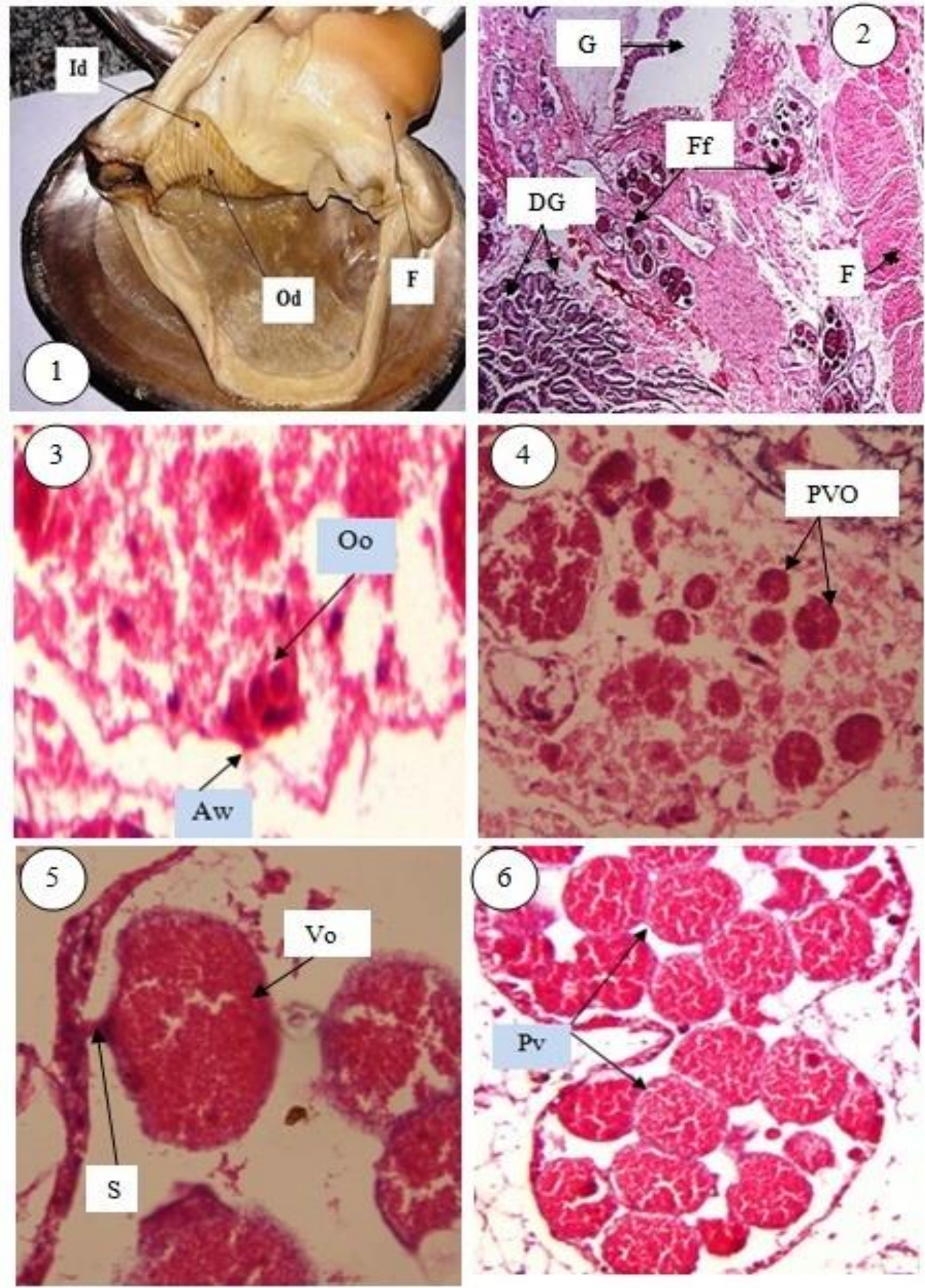

Figs. (1-6): Anatomy and oogenesis of Chambardia rubens. (1) The soft tissue anatomy of $C$. rubens showing foot (F), inner (Id), and outer demibranchs (Od); (2) Histological section in female Chambardia rubens showing visceral mass, the female follicles (Ff) dispersed between the gut $(\mathrm{G})$, digestive gland (DG) and the outer fibromuscular layer of the foot (F), X40. (3-6): Histological sections in the female gonad of Chambardia rubens showing the stages of oogenesis; (3) Oogonia (Oo) located in the acinar wall (Aw), X400. (4) Previtellogenic oocyte (PVO) near the periphery of a follicle, X100. (5) Vitellogenic oocyte (Vo) being detached from the acinar wall through egg stalk (S), X400. (6) Polyhedral postvitellogenic oocytes (Pv) in the acinar lumen, X100. 


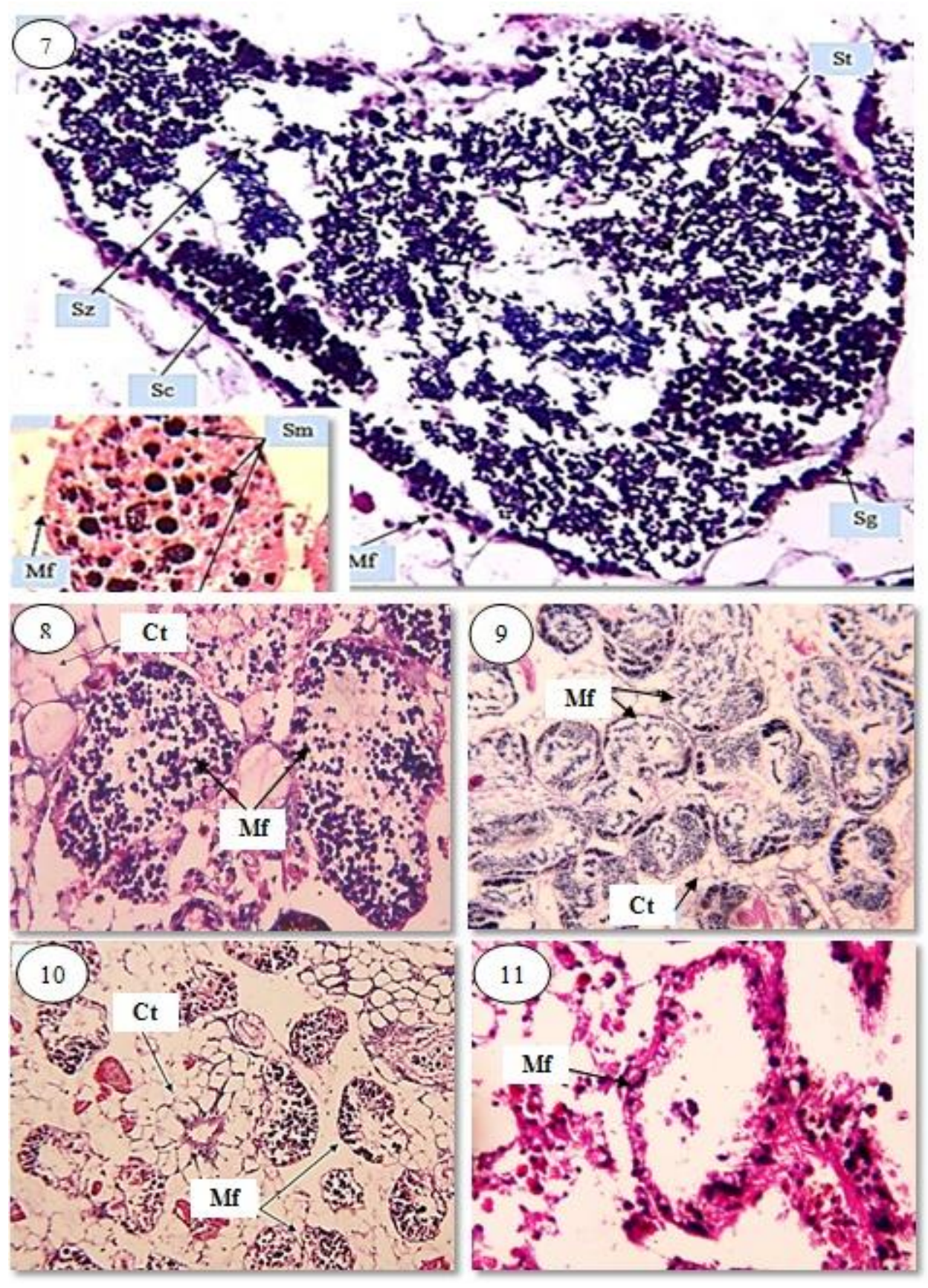

Figs. (7-11): Histological sections in the male gonad of Chambardia rubens showing (7) the stages of spermatogenesis; spermatogonia $(\mathrm{Sg})$, spermatocytes $(\mathrm{Sc})$, spermatid $(\mathrm{St})$, spermatozoa $(\mathrm{Sz})$ within male follicles (Mf), X400. (Fig.7 inset) sperm morulae (Sm) inside the male follicle (Mf), X100. (8-11): The developmental stages within the male follicles surrounded by connective tissues. (8) The developing stage showing follicles with spermatogonia and spermatocytes, X100. (9) The ripe stage showing follicles full of mature spermatozoa, X100. (10) The spawning stage showing the follicle lumen empty from mature spermatozoa, X100. (11) The spent stage showing an empty follicle, X400. 


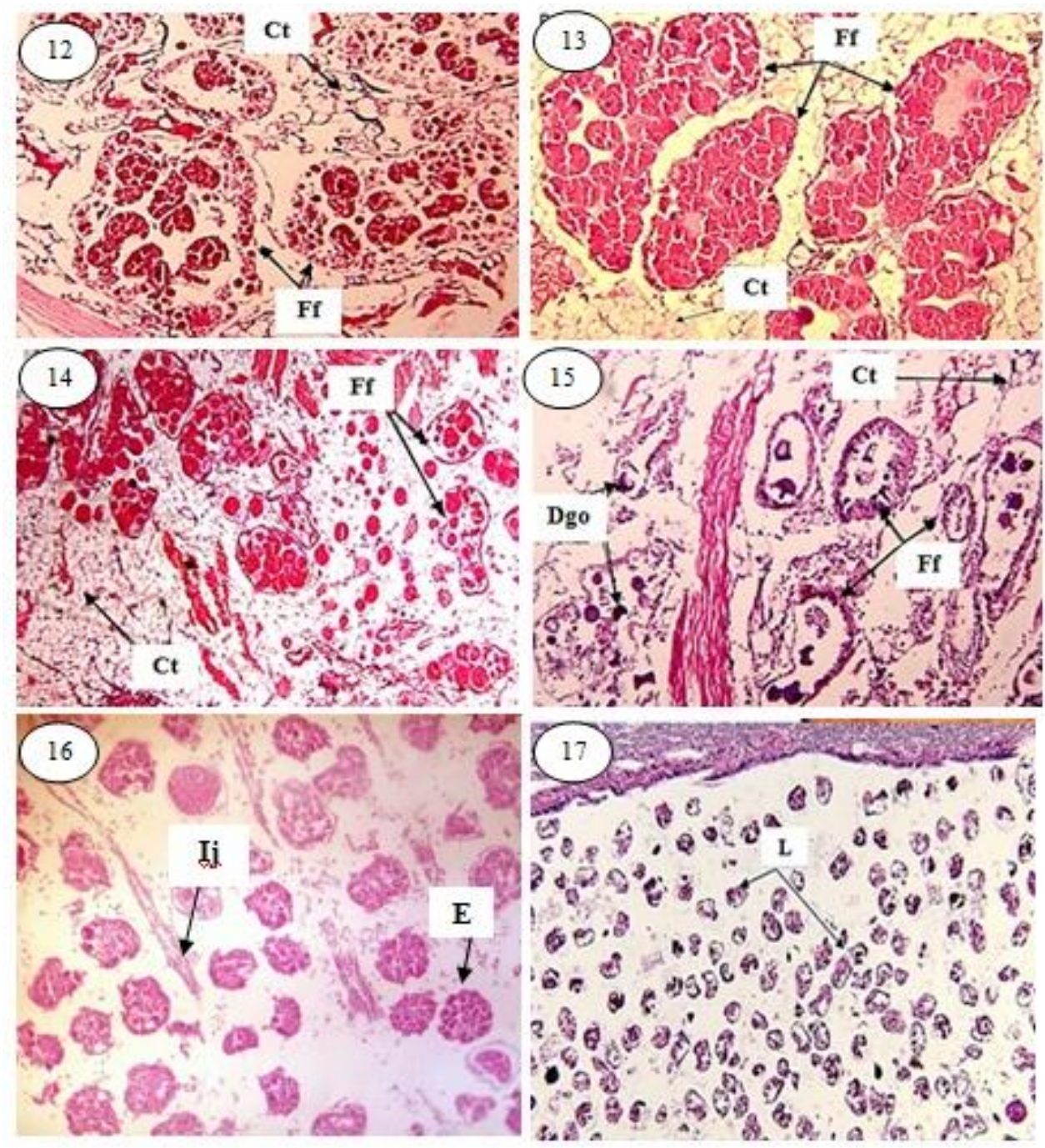

Figs. (12-17): Histological sections in the gonad and ctenidia of female Chambardia rubens showing the developmental stages within the female follicles surrounded by connective tissues. (12) The developing stage, X100. (13) The ripe stage showing follicles full of mature oocytes, X100. (14) The spawning stage, X40. (15) The spent stage of the female follicles (Ff) containing degenerated oocytes (Dgo), X100. (16) Eggs (E) within inner demibrach separated by interlamellar junctions (Ij), X100. (17) Larvae (L) incubated in the inner demibranch, X40. 

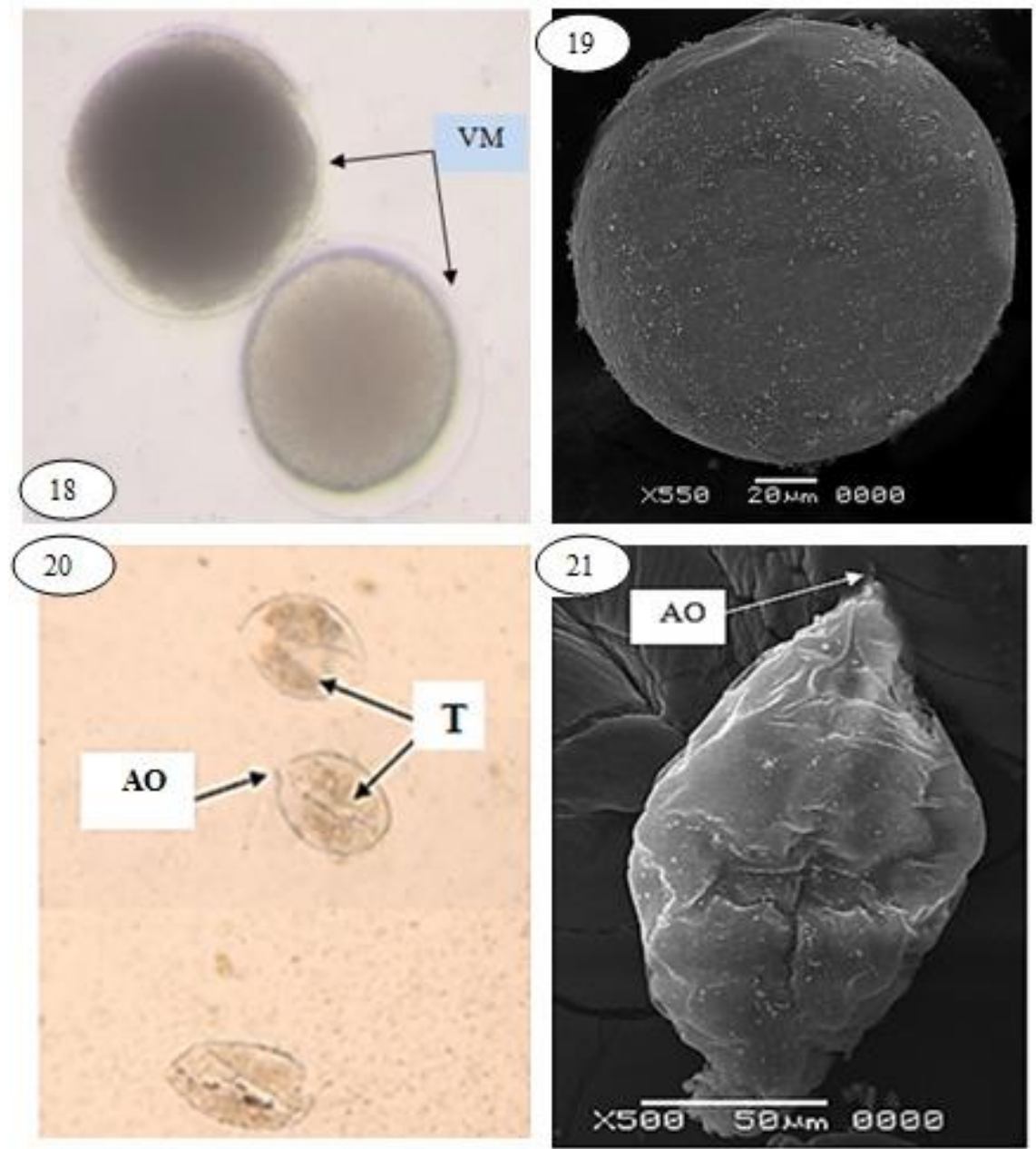

Figs. (18-21): Eggs and larvae morphologies of Chambardia rubens as showed by LM and SEM. (18) Eggs with a vitelline membrane (VM) as shown by LM, X100. (19) SEM micrograph showing egg with a smooth membrane, X550. (20) Larval stages of $C$. rubens with anterior outgrowth (AO) and inner thread (T), X100. (21) SEM micrograph larva showing the anterior outgrowth (AO), X500. 